\title{
Deaf Education as Intercultural Communication: Different Discourses About Deaf Education
}

\author{
Kristian Skedsmo \\ Oslo and Akershus University College of Applied Sciences \\ Kristian.Skedsmo@hioa.no
}

\author{
Keywords: \\ sign language \\ Russian sign language \\ Vygotsky \\ Stalin \\ Marxism and problems of linguistics \\ deaf education \\ bilingualism
}




\section{Abstract}

The traditions, the development, and the objectives of deaf education in Norway and Russia are different. One of the main differences is whether deaf education is in itself seen as intercultural communication, meaning to what degrees the sign language communities are treated as linguistic and cultural minorities or simply as disabled. Neither the Russian nor the Norwegian practice is internationally unique, but the two become recognizable in light of each other, and internationally, they represent two common ways of dealing with education for the deaf today.

This article will discuss what are some of the differences and similarities in deaf education between Norway and Russia related to the status of the two countries' signed languages and whether the deaf populations are viewed either as disabled or as a linguistic minority. The discussion is based on some historical occurrences leading to the current situations in the two countries. Two different discourses, a disability discourse and a minority discourse, will be presented. The disability discourse generally seems to be the most intuitive one among adult newcomers to this field, while the minority discourse more often needs a fair bit of elaboration. Therefore, more space will be devoted to the minority discourse in this article. Furthermore, the description of the differences and similarities in deaf education will draw on the writings of the Russian scholar Lev Vygotsky on (Russian) deaf education and look at what Joseph Stalin wrote about deaf people and language. I shall argue that Vygotsky's suggestions seem to have had more impact in Norway than in Russia, while Stalin's writings seemingly had a great impact on the view on Russian Sign Language (RSL $\left.{ }^{1}\right)$ and the practice and objectives of the Russian schools for the deaf.

I will argue that a hundred years of experience of attempting to make the spoken majority language the first language of deaf children should lead to a change in direction.

\footnotetext{
${ }^{1}$ In Russian: Русский Жестовый Язык (РжЯ)
} 


\section{Introduction}

This article has emerged from the limited and clearly intercultural meeting between myself (a Norwegian Sign Language interpreter, interpreter trainer, and applied linguist) and representatives of the Department of Educating Hard of Hearing and Deaf Children, located at the Faculty of Education at Herzen State Pedagogical University of Russia (HSPUR), two visits to a school for the deaf in St. Petersburg, and conversations with numerous deaf and hearing representatives in this environment. Four meetings have happened through Oslo and Akershus University College's and HSPUR's joint project "Intercultural communication in educational settings". It is necessary to stress that I do not have enough information to give a complete and qualified description of the situation regarding RSL, the situation of Russian deaf people, or the education they are offered. It is also crucial to point out that Norwegian deaf education is far from perfect. Legal rights exist but are not fully implemented. The technical development has brought along several dilemmas, and the mainstreaming of deaf children into ordinary schools is in many cases challenging. I will give a short description of this in the article.

During my conversations and my on-site observations of classroom activities at the schools for the deaf, I experienced distinct differences between the Norwegian and the Russian way of describing and practicing deaf education. While the main goal for Norwegian deaf education was presented as that of teaching the pupils school subjects such as mathematics, geography, language, and history in Norwegian Sign Language (NTS), the deaf education I observed in St. Petersburg apparently had speech training as a core focus in all subjects. All classroom teaching of the deaf pupils was done in oral Russian. Even the workshop teacher I met told me that the pupils always had to pronounce in oral Russian what they were doing (e.g., "I'm drilling a hole"). In a learning environment based on RSL, as in any workshop class for hearing children, the communication would be concerned with the actual learning and the practical work and not with how to pronounce words in a specific language.

The goal of my work is dual. I will try to understand more about how and why the objectives of Russian deaf education have come to be so different from those of Norwegian deaf education, and I will try to explain the perspectives behind the Norwegian version. For the latter, I will use the notion of discourse, and I will give a narrative example. I will make use of quotes from both Stalin's Marxism and Problems of Linguistics first published in 1950 (1976) and several works of the Russian scholar Lev S. Vygotsky, which have been and are still of fundamental value for the perspectives within Norwegian (deaf) education. Seemingly, Vygotsky could have played a central role in Russian deaf education too, but a number of reasons prevented - or at least delayed - his influence.

This article is loosely linked to my oral presentation at a conference at Herzen State Pedagogical University in St. Petersburg on 23 September 2014. The title of the presentation was "Phases and Changes in Norwegian Interpreting Service and the View upon Sign Language."

\section{Signed Languages and Discourses about Deaf Sign-Language Users}

An attempt to describe the "History of deaf education" cannot result in a simple timeline. The fact that different countries and regions move in different directions at different times is an obvious reason, but there are several aspects that make it complicated to describe it as one story. The diachronic picture has to be described as different stories, different lines of evolvement and change and constancy even within one little country such as Norway. I will give a short version of it in the section "Oralism and the Shift to Manualism and Bilingual Education." 
Important and unquestionable influences are of course the Milan Congress in 1880 (Branson \& Miller, 2002), the technological development within the field of auditory technology ${ }^{2}$, and the national legislative amendments that have been made over the years. Even more important and much more complex factors are how these issues have been understood, discussed, and argued about, and how they have been used as reasons for practice - the different discourses.

A discourse in this article refers to a way of talking about an aspect of the world that allows certain descriptions and denies others. A discourse, consequently, can be described as a system of knowledge organizing and defining what can be claimed within a certain field (Pennycook, 1994). Discourse is more abstract than conversation, but still, it only materializes through written text and other kinds of actual language use. "According to social constructionism, our understanding of reality is to a greater or lesser degree constructed through the ways in which we think and talk about this reality, through the ways in which we describe, depict and explain it, that is, through our languages and other sign systems and social conventions" (Kjørup, 2001, p 7, my translation from Danish). Some discourses are generally more common than others, and some are associated with certain groups of people, for example professions and members of a demographic group. Some discourses are more dominant (hegemonic discourses), while others are more local (sub-discourses), or they are opposite to the hegemonic discourse (contra-discourses). The two main ways to talk about deaf signers are often referred to as the medical discourse, focusing on deafness as a defect that should be treated or compensated for in order that they be assimilated into the hearing and speaking society, and the minority discourse (Charrow, 1975), where deaf signers are described as a linguistic and cultural minority. The two discourses provide both Deaf people as well as those working with Deaf people and Deafness - such as educators, medical professionals, technicians, movie makers, journalists, politicians and society at large - with alternative ways of describing, conceptualising and understanding Deafness. The relevant discourse lays down guidelines for decision-making among school authorities and the teachers in the classrooms, for how parents choose for their deaf children, and of course for how deaf people look upon themselves.

\section{Phonocentrism and the Medical Discourse}

Ethnocentrism is the mentality that takes it for granted that our own way of life is the best way for everyone (Sumner \& Keller, 1940). We find it everywhere in our everyday life when we are comparing our own ways of thinking, talking, and acting to those of other people. We compare families, regions, countries, religions, and cultures, and ethnocentrism is easily confused with patriotism and the urge to help others understand their own good. Normocentrism is a variant of ethnocentrism. It is described by Ofstad (1990) and refers to a perspective where being like everyone else is considered necessary for having a good life. As you can see, ethnocentrism and normocentrism are not immoral or at all extreme points of view. They are quite common.

Phonocentrism is a kind of ethnocentrism that takes sound and hearing for granted (Breivik, 2005). It is quite common, but it is one of the main factors in the construction of deaf signers as disabled. We find traces of it in most languages, in expressions like "Did you hear what's happened?", "Let your voice be heard!" and "That's unheard of!" We also recognize phonocentrism in the eagerness to make deaf signers understand spoken language and express themselves orally. Parents of deaf children still may be advised not to learn or to use a signed language to their kids, as that would prevent them from learning spoken

\footnotetext{
${ }^{2}$ The main types of auditory technology are hearing aids and cochlear implants. Hearing aids are battery-driven amplification devices placed outside or inside the ear. Cochlear implants (CI) also consist of a battery-driven external part but in addition have a part that is surgically implanted inside the hearing organ.
} 
language and take some edge off the child's effort to make the most of their residual hearing (Siem, 2008). The normocentric and phonocentric mentality belongs within the medical discourse, where deaf people are described, and hence taught, to see themselves as disabled, sick, abnormal, unfortunate - different from what we want them to be. The result is an educational practice with a focus on normalizing. Obvious examples of normocentrism and use of a medical discourse are when Russian university departments are given names like "Defectology" and "Correctional Education," which undoubtedly highlight the faulty and what needs to be altered. As shown above, there are always alternatives. Being different is not necessarily understood as negative. There are all kinds of differences between people: height, weight, skin color, voice, hairstyle, economy, the kinds of food we like, the way in which we celebrate New Year, and the languages we speak. Some qualities are considered critical by certain people in certain situations. Others are not. Those features that are discussed grow in our minds and in society; others tend not to be topicalized. Some are regarded as positive. Others are not. The ways in which we construct reality by how we talk and write about it are both the tools in these mechanisms and the evidence of what is going on.

\section{The Minority Discourse and a Rather Long Example}

Deaf people have no problems communicating. Unlike early beliefs and contemporary prejudices, signed languages are proven just as "real" (developed, rich, functional, and able to handle abstract issues) as spoken and written languages (Klima \& Bellugi, 1979; Stokoe, 1993). Deaf signers will have trouble talking to anyone they do not have a common language with, but that is of course the situation for all linguistic groups, all over the world. Monolingual individuals can be found both in linguistic majorities and in minorities. Anyone who knows just one language is unable to have conversations with people who do not speak this one language without an interpreter. Still, these monolingual situations are generally not seen as pathologic in any sense. Though it is problematic to claim that all languages are equal because language "richness" is difficult to measure, it seems that many people experience "their own" language to be the most efficient, expressive, and so forth.

Languages can be seen as toolboxes, and they are different from each other. The language of an African desert tribe will probably have a limited vocabulary for various kinds of snow, just like Norwegian has for various camels and signed languages have for various sounds. These differences are no more exotic or unfortunate than the fact that a professional electrician has many words for different kinds of cable and may or may not possess fewer expressions for different dance moves (Lakoff \& Johnson, 1980).

Seeing deaf signers as a linguistic minority rather than as disabled individuals gives one a different perspective. A linguistic minority simply speaks another language. They are just as (un)intelligent, just as (un)gifted and have the same opportunities to learn, discuss, develop, and decide as anyone else - they just use another language. We know that disciplines like history, geography, mathematics, and ethics exist all over the world regardless of languages, and we know that most people in the world would not want to trade their own language for any other. Still, there are many minority languages in the world, spoken and signed, that are not met with the same respect and humility as others. Both in history and in the contemporary world, we find examples of members of minorities who avoid speaking their own language in public, and we experience contra-hegemonic statements, like award-winning Sami-Norwegian artists giving their acceptance speech in a Sami language, which literally no one in the present audience understands (Hansen, 2008), and when the internationally acclaimed Ukrainian movie The Tribe (Slaboshpitsky, 2014) has Ukrainian Sign Language as the only language, without any spoken-language dubbing or subtitles. 
So how can we try to understand the situation of a sign-language minority in an orallanguage majority? In the following hypothetical example, I will try to point out a few features of such a situation.

\section{The Rather Long Example}

Being deaf signers in an orally speaking world can more or less be likened to being a Russian-speaking group in Norway who cannot speak or understand Norwegian but are able to read and write the language pretty well. This scenario should be familiar to many who have travelled in foreign countries. At least the Russian group can still talk unstrained among themselves.

Imagine being part of this Russian group. You all moved to Norway together because you had to, and everyone kept telling you how important it is that you all learn Norwegian. For some odd reason, learning to speak Norwegian seemed almost impossible. No matter how much time and effort you put into it, your attempts at speaking Norwegian would always sound strange, and people would back off when you tried to ask a question or at best give you a puzzled look and speak back to you as if you were a child. Of course, you would continue speaking Russian within the group and avoid the embarrassment of trying to speak Norwegian. Your Norwegian-language teacher said you were doing fine, but every time you tried to order coffee in Norwegian, the girls behind the counter would start giggling. There is a fair chance you would develop a negative feeling about Norwegian and stick to Russian whenever possible.

Imagine the Norwegians asking you why in the world you do not want to speak Norwegian. You have to integrate! They would be worried about your children only playing with the other Russian children, growing up and marrying other Russians. They would claim that the only way to knowledge and social integration is through the Norwegian language. Maybe the Norwegian government would build special schools for Russians, not with Russian-speaking teachers but with Norwegian-speaking teachers whose main goal was teaching the children the Norwegian language. The teachers would do all their teaching in loud and clear Norwegian even though it still seemed almost impossible for the children to learn to understand and to speak Norwegian, and the language training took most of the capacity of the children. The Russian children would probably accept this situation as long as they had no other school experience and as long as they were allowed to speak Russian among themselves during breaks and when the teacher was out of earshot. These schools for Russians might even be boarding schools, and outside the lessons, the Russian language ruled among the kids. School would then be a great meeting place for Russian-speaking kids but would achieve little educational gain since all maths, geography, history, and so forth would be presented and discussed in the less accessible language.

Then imagine that Norwegian couples unexpectedly started having Russian children. For some bizarre reason, the baby did not respond to Norwegian, and after months and maybe even years of health examinations and parental anxiety, some white-coated person sat down with the parents, staring at the table, announcing, "I'm afraid your child is Russian."

Having a foreign child is of course disturbing. The parents had been talking Norwegian to the child from even before it was born. The child behaved like a Norwegian, cried, crawled, and laughed like a Norwegian, and then, everything suddenly seemed to change. The child even had the looks of its mother and father. Then it turned out the child was not like them. It was Russian. The parents consulted every advisor there was. They were not giving up their hope that the child could become like them. Maybe the doctor would warn the parents from taking Russian classes and from speaking Russian to the child. Russian was not a language! It was "not even a linguistic substitute." 
It feels natural to want your own child to speak your own language. It feels natural to want all foreigners in your country to speak your language. It is not natural. It is cultural. It is ethnocentric. As previously claimed, ethnocentrism, normocentrism, or phonocentrism are not evil, but they are the main factors in the construction of deaf signers as disabled and in their marginalization.

This example is not accurate in that it does not correspond to the situation of the deaf signlanguage minorities living surrounded by the hearing, oral-language majorities. More complication would have to be put into it. For example, almost all the individual members of the Russian population in Norway would have been born into Norwegian families. Among these children, there would be different degrees of Russianness in the sense that some Russian children would be more likely to learn Norwegian spoken language than others. Some of these semi-Russians would build a Norwegian identity as semi-capable Norwegians, while others would choose a primarily Russian identity as fully capable Russians with a certain capacity in Norwegian. The Norwegian parents, of course, would celebrate their child's Norwegianness, while the Russian society in Norway would pull in the opposite direction - or they would exclude her as not worthy, calling her a Norwegian-wannabe. This elaboration could go on forever, taking into account identity crises, minority shame and pride, technical development, and medical advice but it will stop here.

\section{Oralism and the Shift to Manualism and Bilingual Education}

In the early nineteenth century, in many places in Europe and America, deaf children were taught in separate schools for the deaf, and the teachers would use the "manual method"signed languages (or at least signed communication). The first schools for the deaf both in Norway (1825) and in Russia (1806) were "manual schools." The International Congress on Education of the Deaf in Milan in 1880 banned signed languages in education, and deaf teachers all over Europe were removed from their positions (Branson \& Miller, 2002). Almost all over the world, the trend shifted from "manualism" to "oralism" in the course of the nineteenth century.

The reintroduction of signed languages, and with it the shift to bilingual deaf education, has been done in different ways at different times across Europe. In Norway, it started in the 1960 s and the 1970s, with signs to support the teacher's speech. In the 1980s, awareness about NTS being a proper language grew, and teachers to various degrees tried to shift from sign-supported speech to NTS. In the curriculum of 1997, deaf children got the right to be taught in NTS and also to have NTS as a separate school subject (Vonen, 1997). If this development had been the only change, we would in Norway today have had three or four schools for the deaf with more than a hundred pupils each, a fertile sign-language environment, and all the teaching performed in NTS. Instead, the government-run schools for the deaf have all but one been shut down, and the last one has only a few pupils. Other changes evidently have had their impact on the result we see today. The overall trend of mainstreaming children into ordinary schools has become dominant with respect to all kinds of disabilities. Along with the advice given by health professionals as well as recent developments in the area of auditory technology, the parents are more likely to choose their local school instead of a school for the deaf that was often far away from their home, forcing the family to move or let the child board at the school. The local school has therefore become the most common choice among parents, the choice which cannot be solely explained in terms of the focus on the development of oral language skills: since 1997, deaf children have had the right to be taught in NTS even at their local school. Norway is in 2016 quite a paradox with the recognition of NTS and the legal rights on the one side and the almost total lack of schools for the deaf on the other.

There are of course many details in the Russian timeline that I am not aware of, but from what I have learned from my visits and conversations with Russian colleagues, the Russian 
schools for the deaf are, according to the parameters mentioned above, where the Norwegian schools were in the 1960s. Nevertheless, I would imagine that many Norwegian deaf children today would envy the Russian deaf children's school breaks, with signing children of all ages everywhere.

In Norway (and other Western countries), Vygotskian ideas about the importance of language and social interaction for cognitive development were quite influential in the shift to reintroduce NTS into the education of the deaf. It might be surprising to some that Vygotskian social constructionism had only a limited impact on deaf education in Vygotsky's own country.

\section{"Vygotsky on Signed Languages and the Education of Deaf Pupils"}

The subtitle is the title of an article by Zaitseva, Pursglove, and Gregory printed in Journal of Deaf Studies and Deaf Education in 1999. It is an edited and adapted version of an article by Zaitseva published in the Russian journal Defektologiya, ${ }^{3}$ which looks into what Vygotsky (1896-1934) said about signed languages and deaf education.

In the 1920s, Vygotsky was clearly skeptical to signed communication, believing it to be primitive and limited and not aspiring to abstract concepts and ideas (Zaitseva, Pursglove, \& Gregory, 1999). ${ }^{4}$. His texts about deaf education are mostly written in the 1920 s and do not make use of the term zhestovy yazyk (sign language) but use the term mimika (mimicry, facial expression). However, Vygotsky also developed skepticism about teaching Russian through the oral approach. He claimed that it diverted attention from all other aspects of education and had disastrous consequences. He found that since spoken language plays almost no part in deaf children's development, it is not to be considered a tool for accumulating cultural experience or for participating in social life. He considered signed languages the natural means of communication and acquiring social experience, but found that neither the manual nor the oral method was acceptable. In "The Fundamental Problems of Defectology" from 1929, Vygotsky regrets the failings of oralism, claiming it had "exceedingly deplorable results" (Vygotsky, 1993).

\section{Vygotsky's Dilemma Regarding Deaf Education}

Vygotsky emphasized the role of language and communication in the development of the child (1967), and his writings have been important for the emphasis on language for the psychological development of any human being. He has even been credited as one of the earliest scholars to point out the advantages of bilingualism (Chipongian, 2000; Lee, 1996). The fact that no known source during Vygotsky's lifetime described signed languages as actual languages but rather as spontaneously created means of simple communication makes it reasonable that he too adapted this perspective and never clearly described RSL as the first language of the deaf population. It is intriguing to speculate about how he would have concluded if he had lived to the age of 64 and read about Stokoe's investigations on American Sign Language, that were published in 1960. Vygotsky's writings from 1929 (1993) suggest that signed languages were created spontaneously and locally within small groups of deaf children. There is a great deal of ambivalence in Vygotsky's "The Fundamental Problems of Defectology" (1993). He describes the shortcomings of the instruction in oral speech and the conflict with the overall aim of education:

\footnotetext{
${ }^{3}$ Zaitseva, G. L.: "Dialog S L.S. Vygostkim o problemakh sovremennoy pedagogiki. [Dialogue with L. S. Vygotsky about the problems of contemporary pedagogy.]" Defektologiya, 1998, No. 2. Reprinted in Kul'turno-istoricheskaya psikhologiya, 2006, No. 3, pp. 21-27.

${ }^{4}$ This is still a very common prejudice about sign languages for newcomers to the field. The prejudice is based on ignoring what is known about how we talk about abstract concepts in spoken languages. We generally speak about abstract concepts as if they were concrete, through metaphors (Lakoff \& Johnson, 1980).
} 
Traditional instruction in oral speech, like a worn cogwheel, did not mesh with the whole mechanism of a child's natural strengths and drives. It did not stimulate inner compensatory activity and was therefore ineffectual. Beaten into children with classical cruelty, oral speech became the official language of the deaf. The task of education, however, must be summed up as a mastery of a child's inner developmental strengths. (Vygotsky, 1993, p. 62)

Believing RSL is not a proper language suitable for the development of thought and consciousness, he leans towards oralism, as he finds it has:

all the advantages over other methods, such as the methods of mimicry (the French method), or the method of manual alphabet (dactylology, writing in the air), because such speech makes communication possible between the deaf and the hearing and serves as a tool for developing thought and consciousness. For us, there was no doubt about the fact that it is precisely oral speech, the oral method, which must be placed at the head of the agenda in education for the deaf-mute. (Vygotsky, 1993, p. 69)

Vygotsky here emphasizes the importance of facilitating communication between deaf and hearing. (He does not mention the possibility that hearing people can learn signed languages or that some deaf children grow up with deaf parents and have a signed language as their family language.) Still, he returns to the disappointing gap between effort and results:

However, as soon as you turn to practice, you will immediately see that this particular question is a question of social education as a whole. In practice, it turns out that instruction in oral speech has produced exceedingly deplorable results. This instruction takes up so much time, and it usually does not teach one to build phrases logically but produces pronunciation in place of speech; it limits vocabulary. (Loc. Cit.)

He reports from the field and admits that "this practical side of life is at odds with the method itself. The pedagogues assert that oral speech is unnatural for the deaf-mute; that this method is unnatural, since it contradicts the child's nature". (Loc. Cit.)

Still, he proposes that the mean be oralism and the goal giving the child a need for oral speech and eliminating the need for "mimicry," as this can better be "verified by life":

In this case, we are convinced that neither the French $^{5}$, the German ${ }^{6}$, the Italian ${ }^{7}$, nor a combined method can offer a way out of this dilemma, that only the socialization of education can offer the solution. If a child has a need for oral speech, if the need for mimicry is eliminated, only then can we be assured that oral speech will develop. I am forced to address the specialists, and they find that the oral method is better verified by life. Within a few years after completion of school, when the students gather together, it turns out that, if oral speech was the condition for the children's existence, then they mastered this speech completely; if they had no need for oral speech, then they returned to the muteness with which they first entered school. (Loc. Cit.)

\footnotetext{
${ }^{5}$ Sign Language.

${ }^{6}$ Oral instruction.

${ }^{7}$ Not described in the text, but according to American Annals of the Deaf and Dumb from 1882, Italian deaf education was oral, but those who "without being idiots" did not gain from this method were sent another place where "a special teacher, by the aid of signs [gave them] instruction adapted to their degree of intelligence" (Fay, 1882, p.56).
} 
I believe that if we look for this "verification" in the situation in Russia (or anywhere else) today, after a hundred years of struggling, we will find that most deaf adults still use their signed language despite their oral education. It looks like sharing a language that is fully accessible and fully functional is fundamental for human beings. Vygotsky tells us that language is essential for our development and for learning. What about the role of language in learning a second language, like the majority's spoken or written language?

\section{A New Direction?}

At a conference on deaf education in 1938, some of the ideas of Vygotsky and his students were contributing to decisions about putting an end to the strict oralism. Spoken (and written) language was still considered the main means of providing logical thinking and allround personality development, but with fingerspelling and RSL as auxiliary means (Zaitseva, 1987). These changes were never fully implemented in Russian education of the deaf. The war might of course have been a fair reason for the slow change, but many texts on the matter put the blame on Stalin's infamous statements in his work Marxism and Problems of Linguistics, released in 1950 (Stalin, 1976).

\section{"Not Even a Linguistic Substitute"}

Stalin's soundbite regarding the status of sign languages as "not even a linguistic substitute" (Shaw, 2011) or "not even a surrogate language" (Pushkova, 2010; Simms, 1997; Zaitseva et al., 1999) is referred to in several articles, books, and webpages as a major reason for the absence of RSL in the classrooms of Russian schools for the deaf. Simms (1997) calls this quote "perhaps the most jaw-dropping example of phonocentric prejudice in the twentieth century" (p. 15). It is quite remarkable that this text should have such a huge impact on Russian deaf education. Instead of trying to understand the enormous power Stalin had, I will look closer into the text, and especially the parts related to RSL and deaf people.

The little book Marxism and Problems of Linguistics (Stalin, 1976) consists of one article, with this title, first published in Pravda on June 20, 1950. This article generated a series of questions submitted by readers and answered by Stalin and published July 4, and August 2 . The article with the questions (edited and shortened) and Stalin's answers were printed and published as a pamphlet later the same year. The main article itself also has a questionand-answer structure, apparently based on questions directed to Stalin by "a group of younger comrades" (p. 3) before he wrote the article. Stalin starts by claiming that he is not a linguistics expert, but that Marxism in linguistics is "something directly in [his] field" (p. 3 ). After this partly humble start, the text answers a number of questions in a quite firm and confident way: "No, it is not true" (p. 3), "No, that is not true" (p. 10), "Yes, it did" (p. 29), "Of course, $[\ldots]$ " (pp. 33, 39).

One central enterprise in the pamphlet is to criticize the linguist and historian N.Y. Marr $(1865-1934)^{8}$ and his claims about a universal proto-language that preceded all existing languages and consisted of four sounds/words and the use of gestures together with these. The ideas of these primitive means of communication were used by Marr to create evidence for his own ideas of "proto-meaning," a theory where man, at the beginning of human language, expressed his primitive, diffuse thoughts in a primitive, diffuse way (Velmezova \& Valsiner, 2012). ${ }^{9}$ Stalin (1976) criticizes Marr and (even more) his followers for creating a "new doctrine" (p. 29) within Soviet linguistics where linguists who "expressed the slightest disapproval of his teachings" were dismissed from their posts (p. 29). Stalin is quite clear in

\footnotetext{
${ }^{8}$ I have not managed to get hold of N. Y. Marr's work. Thus, all my references to his work are secondary.

${ }^{9}$ Vygotsky also took great interest in both gestures and primitive thought, e.g., in "Thought and language" (Vygotsky, 1967).
} 
his criticism of Marr's work, calling it "immodest, boastful and arrogant" (p. 31) and claiming that the proto-language analysis "only gives stimulus to loll in one's arm-chair and tell fortunes in the tea-cup of the four elements" (p. 32).

The "not even a linguistic substitute" quote occurs in the part "Concerning Certain Problems of Linguistics, To Comrades D. Belkin and S. Furer, July 11, 1950" (Stalin 1976 p. 43). ${ }^{10}$ This is the third reply in the pamphlet. It starts with a criticism of the questions: "I have received your letters. Your mistake is that you have confused two different things and substituted another subject for that examined in my reply to Comrade Krasheninnikova."

Stalin's reply to Krasheninnikova (pp. 33-40) is the first, and by far the longest, reply. It shows several questions and answers. One of them is regarding Marx's claim that "language is the immediate reality of thought" (Marx \& Engels, 2011) and the question of whether thought is separable from language, as Marr had suggested. Stalin refers to Marr's text as "labor-magic gibberish" (p. 36) and makes it quite clear that he is on Marx's side in this question (p. 37):

It is said that thoughts arise in the mind of man prior to their being expressed in speech, that they arise without linguistic material, without linguistic integument, in, so to say, a naked form. But that is absolutely wrong. Whatever thoughts arise in the human mind and at whatever moment, they can arise and exist only on the basis of the linguistic material, on the basis of language terms and phrases. Bare thoughts, free of the linguistic material, free of the "natural matter" of language, do not exist.

Not only does Stalin say that he disagrees that it is possible to think without a language or that a thought can exist without linguistic form. He states that such an idea is "absolutely wrong" with the same confidence he shows when he claims that another part of Marr's work is an "incorrect and non-Marxist formula" (p. 31).

The reply to Belkin and Furer (p. 43) starts (as shown above) with a rather harsh rejection of the submitters' (mis)understandings of his previous reply to Krasheninnikova. The submitters ${ }^{11}$ have apparently asked about the nature of deaf signers' thoughts. Stalin does not welcome this subject and argues that instead of accepting or rejecting what he claimed, they introduce what he refers to as "anomalous human beings, people without language, deaf-mutes" (p. 43). Stalin obviously (and expectedly, considering the time) is not aware that signed languages are real, complete languages. On the contrary, he seems quite shocked that such questions could appear, as he considers it "an entirely different subject" (p. 44), as "linguistics concerns itself with normal human beings possessing the faculty of speech and not with anomalous deaf-mutes" (p. 44). This definition of linguistics is of course now considered overtly narrow and outdated, as there has been linguistic research on signed languages all over the world, but before 1960, such work was not generally known.

It seems Stalin (and maybe even the submitters?) confuses RSL with those gestures and hand movements that often accompany spoken languages when he describes it as "an auxiliary means of extremely limited possibilities to which man sometimes resorts to emphasize this or that point in his speech" (p. 45). Given the lack of knowledge about signed languages at the time, it is reasonable to understand this as a description of cospeech gestures. If so, most of us will agree with him that such gestures cannot "replace

\footnotetext{
${ }^{10}$ Unfortunately, the letters with the questions from Belkin and Furer to Stalin is not included in the article. This way, we do not know exactly what they wrote and whether they wrote directly to Stalin or to the newspaper. We only have access to the parts quoted in Stalin's response. It is unclear to me whether the excluded questions were actually printed in Pravda or if the translated and published version (1976) constitutes all the text that was available for the Russian readers at the time.

${ }^{11}$ It is not clear whether both or just one of them has submitted a question regarding deaf people and sign language. The reply mentions "letters", but even though Belkin is referred to two times in the text, Furer is mentioned only in the title.
} 
spoken language" (p. 45); neither can they replace a signed language). We will even agree that such gestures are "not a language, and not even a linguistic substitute" (p. 45). Gestures used in spoken languages have not been included in linguistics until more recent years (Karpinski, 2012).

It seems to be misleading to interpret Stalin's use of the expression "gesture language" (or his reference to Marr's expression "hand language" on p. 44) as referring to "sign language." This probably should better be understood as "gestures," without the confusing mentioning of "language."

\section{Do Deaf People Possess the Faculty of Thinking?}

Stalin's reply to Belkin and Furer does not end with the conclusion that gesture (language) is not a language. Stalin also answers a question regarding Marx's hypothesis about thought's dependence on language and how to apply this idea to deaf signers at the end of the short reply. Stalin accuses Belkin of distraction from linguistics: "Apparently, you are primarily interested in the deaf-mutes, and only secondarily in problems of linguistics. Evidently, it was precisely this circumstance that prompted you to put a number of questions to $\mathrm{me}^{\prime \prime}$ (p. 45). He shows resistance due to the irrelevance of the question but agrees to answer: "Well, if you insist, I am not averse to granting your request" (p. 45).

Apparently, Belkin has asked, "How do matters stand with regard to deaf-mutes? Do they possess the faculty of thinking? Do thoughts arise with them?" I find it difficult to imagine the context of these questions. It would be reasonable to guess that Belkin had a personal interest in this matter, such as a relation to one or more deaf people. Then again, if Belkin knew any deaf people who used RSL, it is difficult to understand how he could possibly question whether they are able to think. If this had happened in Norway in our time, one probable understanding would be that Belkin asked these questions only to provoke the authority and arrange a difficult rhetorical situation for him, but that interpretation is, as I understand it, rather unlikely in this context.

Stalin's conclusions are not easy to follow. Bearing in mind that signed languages were not considered languages and that he strongly advocated Marx's thesis that thoughts "can arise and exist only on the basis of the linguistic material" (p. 37), it is confusing to read his first answer, "Yes, they possess the faculty of thinking and thoughts arise with them" (p. 37). Here, he clearly states that deaf people can think. Then he goes on with "Clearly, since deaf-mutes are deprived of the faculty of speech, their thoughts cannot arise on the basis of linguistic material" (p. 45). This must be read as a diametric contradiction. Initially, the text states that speech is absolutely necessary to be able to think, then that these "speechless" people are able to think, and then that their thoughts exist independently of linguistic material - which he has just argued is impossible. Then he seemingly opens up for Marr's idea about the unverbalized thoughts, which he has so strongly denied. It is tempting to guess that this dilemma strikes him in the act of writing this because the next sentence goes "Can this be taken to mean that the thoughts of deaf-mutes are naked, are not connected with the "standards of nature" (N. Y. Marr's expression)? No, it cannot" (p. 45). This leaves the reader quite puzzled and anticipating a third solution. To sum up these contradictory propositions,

- deaf people have no language;

- language is necessary for thinking; and

- deaf people can think. 
In this way, Stalin opens for languageless thinking by claiming the following:

The thoughts of deaf-mutes arise and can exist only on the basis of the images, sensations and conceptions they form in every-day life on the objects of the outside world and their relations among themselves, thanks to the senses of sight, of touch, taste, and smell. (p. 45)

This is of course very similar to Marr's "non-Marxist" (p. 31) ideas, which Stalin has harshly denied. The last sentence of Stalin's reply to Belkin does not destabilize the already constructed statement that deaf people can think without language, even though such an idea is "non-Marxist" and "absolutely wrong" (p. 37), but emphasizes that "apart from these images, sensations and conceptions, thought is empty, is deprived of all content, that is, it does not exist" (45.).

My reading of Stalin's reply to Belkin clearly shows that Stalin was not aware of the linguistic features of signed languages. Stalin gives two conclusions. The first is that gestures used to accompany speech are not to be considered a language, and the second is that certain thoughts can actually arise without speech.

According to Zaitseva et al. (1999), this text put an end to the reintroduction of RSL in the schools for the deaf in Russia, and the view on RSL in Russia is still negative due to the general understanding of this text.

Marxism and Problems of Linguistics was written in 1950, and its statements about deaf people have reminiscences of the claims by Aristotle (355 BC) that hearing is crucial for learning and that those who are born deaf all become senseless and incapable of reason (Winzer, 1993). This is of course true in the same way that it is true that all human beings that are not communicated with in an intelligible way will become senseless and incapable of reason. The statement presupposes that deaf people are cut off from any communication, that is that signed languages do not exist or are not proper languages. Aristotle merely drew conclusions a bit too fast just like he did when he noticed that deafness correlated with absence of speech and stated that hearing organs and speaking organs were organically connected. Stalin and Aristotle made these claims 66 and 2371 years ago. Since then, it has been proven that signed languages are real languages (starting with Stokoe in 1960), and according to The Council of Europe (2005), approximately twenty-four countries have legally recognized their signed languages. ${ }^{12}$ However, acknowledging a signed language does not mean discarding any attempt at letting deaf people learn the majority language. On the contrary, a bilingual approach serves both languages.

\section{Bilingualism}

Globally, the daily use of two or more languages is the norm rather than the exception (Zurer-Pearson, 2010). The most dominant view on bilingualism among researchers in the field during the last decades is that bilingual or multilingual individuals actually gain from their situation and that they develop some concepts of language earlier than monolinguals. One example is the development of metalinguistic awareness, or the ability to distinguish between a word and its referent, for example understanding that train is a shorter word than caterpillar even though the train itself is by far the longer creature (Basetti, 2011).

\footnotetext{
${ }^{12}$ This has been done in very different ways and with different consequences. Dutch Sign Language is still not officially recognized, but the Netherlands has trained interpreters and is among the leading countries in Europe regarding linguistic sign-language research. The Council of Europe's (2005) report is getting old. A more up-to-date overview can be found at Wikipedia:

https://en.wikipedia.org/wiki/Legal_recognition_of_sign_languages.
} 
For deaf people, being able to read and write the majority language and even lip-read and utter phrases of spoken language in controlled situations are all advantages. These abilities make it possible to read books and newspapers, communicate by text messages and emails, take part in different chat rooms on the internet and maybe take part in some orallanguage encounters. The question is in what way these skills are best developed - by solely focusing on the second language (the spoken/written majority language) or by first giving attention to their first language, their signed language.

Vygotsky (1993) describes the lack of motivation among deaf pupils when it comes to learning spoken language: "In our schools for the deaf-mute, everything conflicts with the children's real interests. All their instincts and drives become not our allies in the cause of education, but our enemies" (p. 69).

Larsen-Freeman and Long (1999) acknowledge the focus on motivation in language learning and date it back to Mowrer (1950), who attributed the child's success in learning its first language to the child's own quest for identity, that is the eagerness to become a member of a linguistic community. For most children, this community is the family, the neighborhood etc. For most deaf children in a school for the deaf, it is the largest ethnolinguistic group on the site: their school peers. This has been the situation for generations of deaf people despite different approaches to teaching. Instead of learning their language from older family members, deaf children have learned from the older pupils at their school and of course from the teachers if these have used the relevant signed language.

\section{The Bilingual and Bicultural Approach}

Bilingual education for deaf children consists of treating their signed language as their first or native language and the majority's spoken/written language as the second language. Many schools for the deaf have become bilingual schools, like A. C. Møller School in Norway and Manillaskolan in Sweden. Svartholm (2010) sums up the history of bilingual deaf education in Sweden and describes the path from oral teaching through "signed Swedish"13 to a true bilingual approach where Swedish Sign Language is the language of teaching and face-to-face communication and written Swedish is the written language. The evaluation made in 1993 compared these pupils' results with those of former pupils during the manual and "signed Swedish" approach and with those of hearing pupils in ordinary schools. The evaluation showed that the signing pupils performed significantly better both in understanding written Swedish and in other academic tasks than the orally and "signed Swedish"-educated pupils. The bilingually educated deaf pupils' reading abilities were also found to be fully comparable to those of hearing pupils at the same age (Svartholm, 2010). A Dutch research project (Hermans, Knoors, Ormel, \& Verhoeven, 2008) investigating deaf pupils in a bilingual program also shows positive correlations between sign vocabulary and reading vocabulary.

Even though researchers within the fields of language and language acquisition practically agree on the importance of having at least one fully accessible and functioning language as a base for learning other matters and other languages, we still see school failure among language minority children. Macswan (2000) directs the attention to prescriptivism, the ethnocentric idea that one language is of inherently higher value than others, and semilingualism, which refers to the idea that the child knows only half of a language. Bilinguals tend to have different language competence in their two languages (often related to different domains of their lives) but have sometimes been claimed to suffer from double semilingualism (Hinnenkamp, 2005).

\footnotetext{
${ }^{13}$ Swedish spoken language with support of signs borrowed from Swedish Sign Language.
} 
Language and culture are closely tied together, and it can be difficult to distinguish where the one ends and the other starts. Several studies have been done that display the deaf minority as not only a linguistic minority but also a cultural minority (Grosjean, 2010; Ladd, 2003). Therefore, hearing teachers facilitating learning for deaf pupils is a bicultural enterprise.

\section{The Role of First Language for Children with Linguistic-minority Backgrounds}

Learning mathematics, history, geography and other disciplines in a language you have limited access to is of course less effective than learning in a language you master and share with your teachers. What about learning languages? Learning a language with limited access, like deaf people learning an oral language or hearing people learning a language they never get to hear, is possible but obviously harder than learning an accessible language.

Treating a signed language as the pupil's first language also means having the relevant signed language as a separate subject. As Norwegian children study Norwegian at school, deaf pupils in bilingual schools learn about NTS. This of course requires a high level of signlanguage fluency among the teachers and the child's caretakers and also academic linguistic knowledge about this signed language. In Norway, hearing parents with deaf children are offered 40 weeks of training in NTS, and teachers of NTS are obliged to study NTS for six months or a whole year (depending on the class level). In the plans for the new five-year teacher-education program in Norway, ${ }^{14}$ NTS is also treated as a prioritized subject, being one out of five "master subjects."

Early research has shown that an academic knowledge about your first language is important for learning the various school subjects. Collier (1995), doing research on (hearing) children with diverse linguistic-minority backgrounds in English-speaking schools in the United States, found that "in U.S. schools where all instruction is given through the second language (English), non-native speakers of English with no schooling in their first language use 7-10 years to reach the age and grade-level norms of their native Englishspeaking peers" (p. 7). When the pupils have to speak their second language, they function at a cognitive level far below their age (p. 8).

Having a well-developed first language, for example NTS or RSL, will also have an impact on how the pupils learn in a second-language educational setting:

Many studies have found that cognitive and academic development in the first language has an extremely important and positive effect on second language schooling (e.g. Bialystok, 1991; Collier, 1989, 1992h; Garcia, 1994; Genesee, 1987, 1991; Thomas \& Collier, 1995). Academic skills, literacy development, concept formation, subject knowledge, and learning strategies developed in the first language will all transfer to the second language. As students expand their vocabulary and their oral and written communication skills in the second language, they can increasingly demonstrate their knowledge base developed in the first language. (Collier, 1995, p. 8)

Jim Cummins's theory on the language interdependence notions of BICS (Basic Interpersonal Communication Skills) and CALP (Cognitive Academic Language Proficiency; Cummins, 2003) stresses that if the children get to develop CALP in their first language (e.g., a signed language), they will learn the second language more easily. Developing

\footnotetext{
${ }^{14}$ The five-year teacher-education program is to be implemented in 2017 according to the Norwegian government (https://www.regjeringen.no/no/aktuelt/Innforer-5-arig-grunnskolelarerutdanning-pa-masterniva/id761439/).
} 
CALP, according to Cummins, usually takes around five years. Such findings indicate that deaf children will need five years of exposure to their native sign language before they move into CALP and are ready to learn their second language in the most efficient way. Considering the fact that most deaf children grow up in hearing families with no prior skills in the relevant signed language, this transition will probably take even longer. Deaf children attending school with minimal sign-language proficiency will thus have problems learning the less accessible written and especially spoken majority language. This will also make the acquisition of other subjects through the medium of the majority language difficult.

\section{Conclusions}

Different discourses highlight different parts of reality and create different problems and different solutions. In a disability discourse, variation is a problem and needs to be solved. A minority discourse highlights linguistic, cultural, and sometimes ethnic differences, like those often discussed related to migration. Such variations are dealt with in different ways in different parts of the world. Mainstreaming, that is assimilation of minorities, is a goal in many majority cultures. Segregation is often seen as the other end of the same scale, while inclusion usually refers to the acceptance of variation, facilitating bilingualism and biculturalism (Schuman, 2011).

As Vygotsky (1993) said, "for the deaf, only the organ for hearing is affected; all remaining organs are healthy." This leads to the conclusion that if they are met by teachers and caretakers who accept them and speak their language, there is no obvious reason that they should have to spend two more years in school than hearing children. This was put into action at the Moscow bilingual school for the deaf (Zaitseva et al., 1999), but I have learned that the school does no longer exist.

Rejecting a signed language does not make deaf children any more hearing. Recognizing the fact that deaf people all over the world choose to use signed languages among themselves is to acknowledge that these languages are functional to them. Vygotsky said, "Language does not of necessity depend on sound. There are, for instance the sign language of deaf-mutes and lip reading [...] In principle language does not depend on the nature of its material" (Vygotsky, 1967, p. 38). ${ }^{15}$ Recognizing deaf sign language users as a linguistic and cultural minority makes deaf education (when facilitated by the majority) intercultural communication. A school for the deaf can simply be a school where a signed language is the language in the classroom, like English is at The International School of Moscow and the Oslo International School in Norway or like Russian is at the Russian Embassy School in London. Thus, deaf children can learn and develop like other children. To quote Vygotsky again, "one should and must approach a blind and a deaf-mute child, psychologically and pedagogically, with the same standard used for a normal child" (Vygotsky, 1993, p. 68).

A hundred years of attempts to make the spoken majority language the first language of deaf children have taught us that deaf sign-language users tend to stay deaf sign-language users despite their oral education. Knowing that signed languages are complete, fully functional languages that can serve as tools both for conversation and for thought makes such a situation less threatening.

\footnotetext{
15 These remarks belong to the chapter "The Genetic Roots of Thought and Speech" and actually occur in a section discussing experiments on teaching chimpanzees to speak in order to find out whether they have intelligence comparable to that of humans. Vygotsky suggested that they try with "the sign language of the deaf-mute" (p. 38) because it had never been tested. Since then, there have been done several attempts to teach chimpanzees sign language. Some animals learned several hundred signs, but none of them could actually learn a human language and participate in conversations like a human being (Saxton, 2010). It is problematic when enthusiastic researchers proclaim that they have taught an animal sign language because this gives an erroneous impression of signed languages.
} 


\section{References}

Basetti, B., Cook, Vivian. (2011). Language and cognition: The second language user. Hove, UK: Psychology Press.

Branson, J., \& Miller, D. (2002). Damned for their difference: The cultural construction of deaf people as disabled: A sociological history. Washington, D.C.: Gallaudet Univ. Press.

Breivik, J.-K. (2005). Deaf identities in the making: Local lives, transnational connections. Washington, D.C.: Gallaudet University Press.

Charrow, V. R., Wilbur Ronnie B. (1975). The deaf child as a linguistic minority. Theory Into Practice, 14(5), 353-359. http://dx.doi.org/10.1080/00405847509542599

Chipongian, L. (2000). The cognitive advantages of balanced bilingualism. Brain Connection. Retrieved 9 August 2016 from http://brainconnection/the-cognitive-advantages-of-balanced-bilingualism/

Collier, V. P. (1995). Acquiring a second language for school. Directions in Language \& Education, 1(4), 3-14.

Cummins, J. (2003). BICS and CALP. Retrieved 3 May 2015 from http://iteachilearn.org/cummins/bicscalp.html

Fay, E. A. (1882). Notices of publications. American Annals of the Deaf and Dumb, 27 (1), 55-61.

Grosjean, F. (2010). Bilingualism, biculturalism, and deafness. International Journal of Bilingual Education and Bilingualism, 13(2), 133-145. http://dx.doi.org/10.1080/13670050903474051

Hansen, J. (2008). Prisdryss over nordnorsk film (Shower of awards for North Norwegian movies). Retrieved 9 august 2016 from http://www.itromso.no/kultur/article175553.ece

Hermans, D., Knoors, H., Ormel, E., \& Verhoeven, L. (2008). The relationship between the reading and signing skills of deaf children in bilingual education programs. Journal of Deaf Studies and Deaf Education, 13(4), 518-530.

http://dx.doi.org/10.1093/deafed/enn009

Hinnenkamp, V. (2005). Semilingualism, double monolingualism and blurred genres - on (not) speaking a legitimate language (1). JSSE - Journal of Social Science Education, 4(1), 57-90.

Karpinski, M. (2012). The boundaries of language: Dealing with paralinguistic features. Lingua Posnaniensis, 54(2), 37-54. http://dx.doi.org/10.2478/v10122-012-0013-1

Kjørup, S. (2001). Den ubegrundede skepsis: En kritisk diskussion af socialkonstruktivismens filosofiske grundlag. Sosiologi i dag, 1(2), 5-22.

Klima, E. S., \& Bellugi, U. (1979). The signs of language. Cambridge, Mass.: Harvard University Press.

Ladd, P. (2003). Understanding deaf culture: In search of deafhood. Clevedon, UK: Multilingual Matters.

Lakoff, G., \& Johnson, M. (1980). Metaphors we live by. Chicago: University of Chicago Press.

Larsen-Freeman, D., \& Long, M. H. (1999). An introduction to second language acquisition research. (10th ed.). London: Longman Group.

Lee, P. (1996). Cognitive development in bilingual children: A case for bilingual instruction in early childhood education. The Bilingual Research Journal, 20(3 \& 4), 499-522. http://dx.doi.org/10.1080/15235882.1996.10668641 
Macswan, J. (2000). The threshold hypothesis, semilingualism, and other contributions to a deficit view of linguistic minorities. Hispanic Journal of Behavioral Sciences, 22(1), 345. http://dx.doi.org/10.1177/0739986300221001

Marx, K., \& Engels, F. (2011). The German ideology. Malden, Mass.: Wiley-Blackwell. Mowrer, O. H. (1950). Learning theory and personality dynamics. New York: Ronald Press. Ofstad, H. (1990). Vi kan ändra världen: Hur bör vi ställa frågorna? Stockholm: Prisma. Council of Europe (2005). The status of sign languages in Europe. Strasbourg: Council of Europe Publishing.

Pushkova, D. (2010). Deaf people in Russia fight to make themselves heard. Retrieved 4 May 2015 from http://on.rt.com/cfs9kq

Saxton, M. (2010). Child language acquisition and development. Thousand Oaks, CA: SAGE Publications Ltd.

Shaw, C. L. (2011). Deaf in the USSR: "Defect" and the New Soviet Person, 1917-1991 (PhD dissertation). University College London: London.

Siem, G., Wie, O. B., \& Harris, S. (2008). Cochleaimplantat og tegnspråk. Tidsskrift for Den norske legeforening, 1, 69.

Simms, K. (1997). Translating sensitive texts: Linguistic aspects. Amsterdam: Rodopi.

Slaboshpitsky, M. (Writer). (2014). The Tribe (Плем'я) [Movie ].

Stalin, I. V. (1976). Marxism and problems of linguistics. Peking: Foreign Languages Press.

Stokoe, W. C. (1993). Sign language structure: An outline of the visual communication systems of the american deaf (Republ. ed.). Burtonsville, MD: Linstok Press. http://dx.doi.org/10.1353/sls.1993.0017, http://dx.doi.org/10.1353/sls.1993.0001

Sumner, W. G., \& Keller, A. G. (1940). Folkways: A study of the sociological importance of usages, manners, customs, mores, and morals. (2nd ed.; 1st electronic ed.). Boston: Ginn and Co.

Svartholm, K. (2010). Bilingual education for deaf children in Sweden. International Journal of Bilingual Education and Bilingualism, 13(2), 159-174. http://dx.doi.org/10.1080/13670050903474077

Velmezova, E., \& Valsiner, J. (2012). The eternal return to the issue of "primitive thought": Lev Vygotsky and N. Marr looking at L. Lévy-Bruhl. RIFL, 6(2), 228-234. doi: $10.4396 / 20120720$

Vonen, A. M. (1997). 1997: Et merkeår i døveundervisningens historie. Oslo: Skådalen kompetansesenter.

Vygotsky, L. S. (1967). Thought and language . (E. Hanfmann \& G. Vakar, Eds. and trans.). Cambridge, Mass: MIT Press.

Vygotsky, L. S. (1993). The collected works of L. S. Vygotsky. Volume 2: The fundamentals of defectology (abnormal psychology and learning disabilities). (R. W. Rieber \& A. S. Carton, Eds. Translation and introduction by J. E. Knox \& C. B. Stevens). New York: Plenum Press.

Winzer, M. A. (1993). The history of special education: From isolation to integration. Washington, D.C.: Gallaudet University Press.

Zaitseva, G. (1987). Problems of sign language in the Soviet deaf education. In J. Kyle (Ed.), Sign and school: Using signs in deaf children's education (pp. 100 - 108). Clevedon Philadelphia: Multilingual Matters.

Zaitseva, G., Pursglove, M., \& Gregory, S. (1999). Vygotsky, sign language and the education of deaf pupils. Journal of Deaf Studies \& Deaf Education, 4(1), 9-15. http://dx.doi.org/10.1093/deafed/4.1.9

Zurer-Pearson, B. (2010). We can no longer afford a monolingual norm. Applied Psycholinguistics, 31(2), 339-343. doi:10.1017/S014271640999052X. http://dx.doi.org/10.1017/S014271640999052X 